Int. J. Dev. Biol. 50: 245-253 (2006)

doi: $10.1387 / \mathrm{ijdb} .052103 \mathrm{rg}$

\title{
Mechanics in embryogenesis and embryonics: prime mover or epiphenomenon?
}

\author{
RICHARD GORDON* \\ Departments of Radiology, Computer Science and Electrical \& Computer Engineering, University of Manitoba, Health Sciences Centre, \\ Winnipeg, Canada
}

\begin{abstract}
Mechanics is shown to be an important, perhaps central component to the differentiation and development of embryos. Mechanics of the nucleus may also be involved in determining which genes are expressed in a given cell. There are two major approaches at present to the mechanics of differentiation in embryos: morphomechanics and differentiation waves. These are compared in detail, to provide a starting point for future experimental work to bring them into one conceptual framework. This may rationalize the present cookbookery of stem cell production by placing it in the context of differentiation waves and the differentiation code. Embryonics, the realization of concepts from embryology in computer hardware and software, might be considerably enhanced by incorporating mechanical concepts of embryogenesis. Segmented robots, modular robotics, cellular microrobotics, flexible electronics, wearable computers, diatom nanotechnology and waves in active media point to a synthesis that we could call embryonic robotics.
\end{abstract}

KEY WORDS: embryo physics, differentiation wave, morphodynamics, differentiation code, artificial life

\section{Introduction}

The ascendancy of molecular biology over the past half century has left untraveled and abandoned roads in biological research. One of them began in earnest with the efforts of Basel born Wilhelm His to explain neural tube closure by analogy to the mechanical buckling of laminates (His, 1874). The idea was that forces pushing from the flanks of the embryo towards the midline caused the buckling. Unfortunately, reality interceded when Wilhelm Roux slit the sides of a frog embryo and the neural plate buckled and formed a neural tube anyway (Roux, 1888). The solution to this impasse can be seen in the three dimensional model of Jacques Loeb (Figure 1), in which the lateral forces of buckling are generated by stretching in the perpendicular direction (a prediction later shown to be correct, with stretching provided by the notochord and/or notoplate (Jacobson and Gordon, 1976; Gordon and Jacobson, 1978; Keller, 1984). Loeb said:

"If we take a thin, flat plate of elastic rubber and lay it on a drawing-board, we can imitate the stronger growth in the center by sticking two tacks into the middle of the rubber, a short distance apart and then pulling them in opposite directions. In this way we may imitate unequal growth, the center growing faster than the periphery. If we then fix the tacks in the drawing-board, so that the rubber in the middle remains stretched, we get the same system of folds as that shown by the embryo of a chick. I mention this way of demonstrating the effects of unequal growth as the ideas of His are still doubted by some morphologists" (Loeb, 1912).

Indeed, except for Loeb, who generally avoided discussing internal mechanisms (Pauly, 1987) and a few others (Glaser, $1914 a, b ; 1916)$, His' mechanical approach to embryos almost vanished from the scientific literature. His was also vehemently opposed by Ernst Haeckel, which didn't help (Oppenheimer, 1967).

The biggest foray last century into the mechanics of development, which unfortunately has little impact in embryology, perhaps because it eschewed genetics (Keller, 2000), is that of D'Arcy Thompson in his book On Growth and Form (Thompson, 1917, 1942). Thompson's transformations have proved useful in tracking shape change (Kavanagh and Richards, 1942; Richards and Kavanagh, 1943, 1945; Burnside and Jacobson, 1968; Jacobson and Gordon, 1976a; Gordon and Jacobson, 1978; Bookstein, 1978; Bookstein et al., 1985; Bookstein, 1991), but not, so far, in uncovering underlying mechanisms. For example, given that the mitotic apparatus appears to swing in the direction of elongation of elongated gourds, such as the snake gourd, but is random in round gourds (Sinnott, 1960), one would expect that directed cell division would be responsible for plant shape. However, this has been shown to be false for leaf shape (Smith et al.,

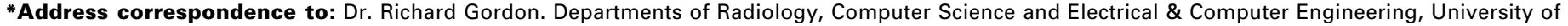
Manitoba, Health Sciences Centre, 820 Sherbrook Street, Winnipeg, MB R3A 1R9 Canada. Fax: +1-204-787-2080. e-mail: GordonR@ms.UManitoba.ca
} 
1996). Whole leaf mechanical approaches haven't solved the problem (Hay et al., 2000). Similar questioning is needed for oriented cell division in neuroepithelium (Sausedo et al., 1997).

We are now exiting a long era of genetic determinism, the idea that somehow (His' quite valid "To think that heredity will build organic beings without mechanical means is a piece of unscientific mysticism", His, 1888) "genes control development" (Probst et al., 1992). This awakening from a long sleep of reason is occurring in fits and starts. My intention here is to give the reader a sampling of research demonstrating roles of mechanics in embryology and then try to consolidate the two superficially different approaches in my research (differentiation waves) and that of Lev V. Beloussov (morphomechanics). These mechanical approaches have the curious consequence of reopening the question of whether development is an interaction between cells, or a phenomenon involving the whole organism. I resurrected this old challenge to the cell theory (Gordon, 1999) and it is the central theme of a new book (Pivar, 2004; Gordon, 2006). I will end by considering possible implications of all of this for rationalization of the production of tissues from stem cells and for embryonics, the idea that we should create computers that build themselves by analogy to the self-construction of embryos.

\section{Atoms versus form}

Any time-lapse movie of a developing organism shows the lie that it is all chemistry. Embryo-scale mechanical effects are blatant, if unexplored and thus unexplained. While at the level of macromolecules, motor molecules abound (Schliwa, 2002) and may be the points at which ATP and GTP provide the ultimate chemical source of energy for the generation of mechanical forces, the spatial and mechanical organization within cells and between cells may govern what happens. This intellectual tension

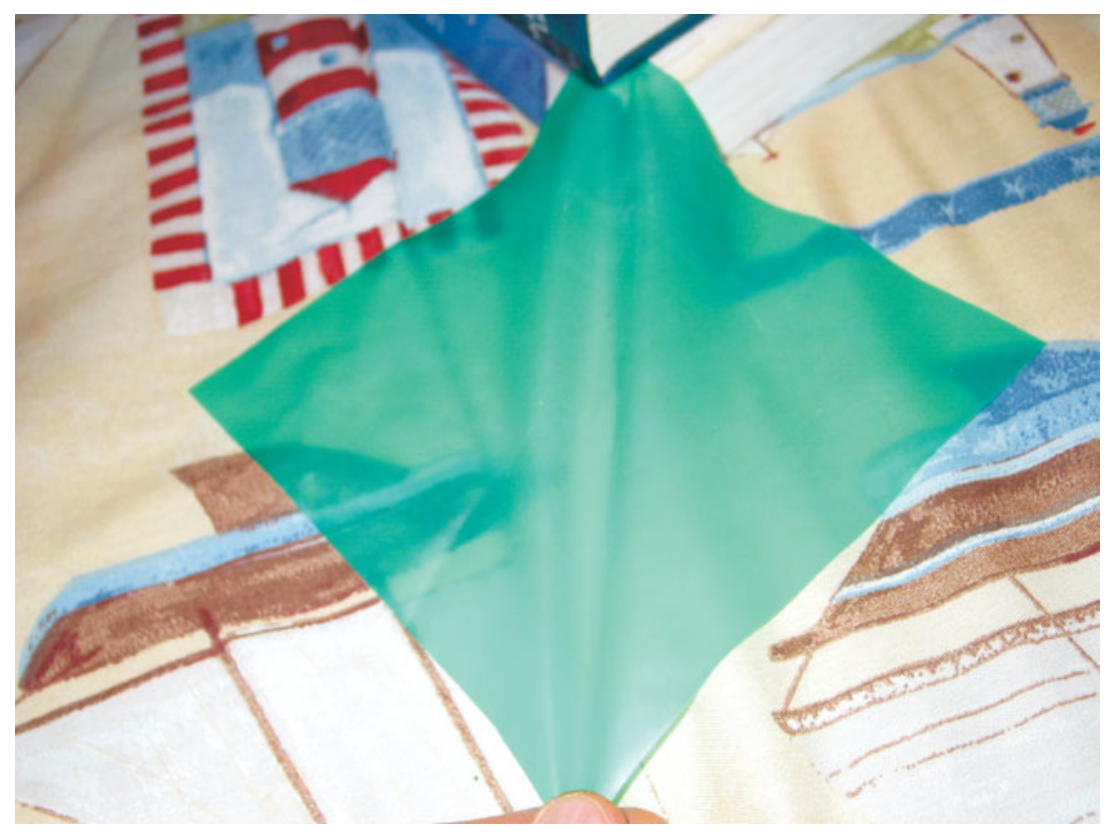

Fig. 1. Stretching of a sheet of rubber (dental dam) leads to neural tube formation by lateral compression, even though there is no external force pushing the sheet laterally (Loeb, 1912). between the ancient Greek idea that all that counts is the motion of atoms, versus higher order structure, has been explored nicely for single cells by Franklin Harold (Harold, 2001b), who moves the problem all the way back to the origin of life.

Is there a way to resolve this tension? Physics, at least until recently, told us that there is "nothing but" the interaction of matter and fields (electromagnetic, gravitational, etc.). While we're not so sure about this, with the discovery that the material of the universe is only $4.4 \%$ baryons (Bennett et al., 2003) and acceptance of quantum entanglement as a real phenomenon (cf. Gordon et al., 2005b), it would seem that the interaction model might be sufficient to explain living phenomena. On that basis, classical statistical mechanics provides an example of what I call a "linking discipline" (Proposition 194 in Gordon, 1999), in which the hard intellectual work of linking one level of explanation to another, is done. I would contend that for embryology, this work has hardly begun.

For example, in terms of genetics, we have not yet solved the "simplest" morphogenetic problems:

"We are... exceedingly well informed about bacterial biochemistry, metabolism and genetics. One might expect, therefore, that how bacteria grow and shape themselves would be quite well understood. That is not the case and for a significant reason: even in bacteria, form is the result of multiple coordinated processes, regulated in time and localized in space, that are but indirectly related to what is spelled in the genes" (Harold, 2002).

"I hold the mildly heretical view... that the genetic paradigm as it stands is insufficient, incomplete and fundamentally misleading. Briefly, biological organization is made up of multiple layers, which span the range from molecules to cells [to embryos, adults, populations, ecologies and biospheres]. Genes do, of course, specify order at the level of molecules and supramolecular complexes that arise by self-assembly, such as ribosomes. But molecular structures do not suffice to specify cellular structure, for cells do not arise by self-assembly of their molecular constituents" (Harold, 2001a).

A similar challenge, now of practical importance for "growing nanotechnology" (Gordon etal., 2005a), lies in bridging the intellectual gap between genome sequencing and morphogenesis of diatom shells (Drum and Gordon, 2003; Gordon and Parkinson, 2005). We can be quite certain that the currently popular network approaches, attempting to simulate the gene products of the whole genome (Tyson et al., 2001; de Jong, 2002), will not solve the problem of form of bacteria, let alone form of multicellular organisms, despite the enthusiasm for this approach:

"One of the foremost challenges of 21 st century biological research will be to decipher the complex genetic regulatory networks responsible for embryonic development" (Halfon and Michelson, 2002).

The reason for impending failure is that network models do not include the physics of the organism. For example, some bacteria have an internal pressure of about one atmosphere (Arnoldi et al., 2000) and amphibian embryos reach 7 atmospheres (Beloussov, 1998), suggesting that physics may be quite important for both. 
Physics can have a global effect on a cell or organism. The relevant physics might include:

1. Volume effects, 2. Electrical effects, 3. Optical effects, 4. Magnetic effects and 5. Mechanical effects. I'll give just brief examples of the first four:

1. The ratio of the volume of cytoplasm to the volume of the nucleus has an effect on the cell division time and has been modeled in sea urchin embryos (Ciliberto et al., 1999). Basal metabolism, dependent on this ratio, affects ecology and evolution (Martin and Gordon, 1995).

2. There is an elegant model for the formation of polarity in the spherically symmetrical algal (single-celled) egg of the seaweed Fucus, in terms of current generating ion channels that move together in the cell membrane (Jaffe et al., 1974; Robinson and Jaffe, 1975). Electric (ionic) current passes out of the neural plate in chicks (Jaffe and Stern, 1979) and regenerating limbs (Borgens et al., 1977).

3. Cells can apparently "see" and move in a directed fashion in response to infrared light (Albrecht-Buehler, 1992).

4. Fruit fly embryos develop abnormal segmentation patterns when briefly exposed to weak, static magnetic fields at a critical period (Ho et al., 1992; Ho, 1998).

These phenomena have not been consolidated into explanations of how embryos form or organisms regenerate and tend to be ignored.

\section{Mechanical control of genes}

The best antidote to the oft repeated expression that "genes control... X" is to read the literature about X controlling genes. The evidence for mechanical control of gene expression starts with the work of Avri Ben-Ze'ev, who investigated changes in gene expression in cultured cells that depended on whether they were attached to a substrate or suspended free in a gel, otherwise being in the same medium (Ben-Ze'ev et al., 1980; Ben-Ze'ev, 1983; Farmer et al., 1983; Ben-Ze'ev, 1984a,b, 1985). He concluded that "the cytoskeleton may regulate gene expression" (Ben-Ze'ev, 1991). Donald Ingber and his colleagues have placed cells on substrate spots or squares, surrounded by hydrophobic substrate to which they do not adhere and found that cells differentiate at a specific spot size (Ingber and Folkman, 1989; Mooney et al., 1992; Chen et al., 1997, 1998; Dike et al., 1999; Huang and Ingber, 2001). Ingber concludes: "Thus, mechanical restructuring of the cell and cytoskeleton apparently tells the cell what to do" (Ingber, 1998).

\section{Reciprocity between the genome and mechanics}

There is much discourse on the emergence of "higher order" properties from the interaction of lower order "units" (Emmeche, 1994; Holland, 1998; Ronald et al., 1999; Johnson, 2001; Gordon, 2000), some of it reaching religious conclusions (Morowitz, 2002). However, most seem to miss what I regard as the essence of the problem: higher order, so-called emergent phenomena can feed back on the lower order phenomena and alter them. Let's take the extreme of our own conscious behavior. While we cannot alter the basic laws of physics, by changing boundary conditions, we can alter what physics happens (Martin and Gordon, 2001).

A more mundane example is the "higher order" phenomenon of surface tension ( $\$ 1.10$ in Gordon, 1999). The adhesion of embryo cells of the same and different kinds behaves quite similarly to mixed oil and water: like separates with like "due to" the interfacial tension (Townes and Holtfreter, 1955; Steinberg, 1963; Phillips and Steinberg, 1969; Phillips et al., 1972; Gordon et al., 1975; Phillips et al., 1977; Phillips and Steinberg, 1978; Edelman, 1988; Steinberg, 1996). Of course, in this case we have developed the statistical mechanics of interfacial tension to the point where we are quite comfortable in switching between the molecular and macroscopic levels without worrying about philosophical consequences. In this sense, the emergence seems trivial, the awe is gone and the problem seems solved in essentially reductionist terms. The initial boundary conditions are either the arrangement of cells in an embryo when adhesion phenomena are "turned on" (via synthesis of certain membrane bound molecules, Edelman and Jones, 1998), or the configuration in which we place such cells in experiments.

I suspect, if we work at it long and hard enough, we will achieve the same degree of reductionism and understanding of boundary conditions for all of embryological development. The agenda was set out for us by His, but no one is yet doing the sustained work required of us:

"The ways of determining the forms and volumes of germs and embryos are somewhat longer and more tiresome than the simple inspection of stained sections; but the general scientific methods of measuring, of weighing, or of determining volumes cannot be neglected in embryological work, if it is to have a solid foundation of facts, for morphologists have not the privilege of walking in easier or more direct paths than workers in other branches of natural science" (His, 1888).

In the synthesis of adhesion molecules, the role of the genome is to turn on their synthesis at the right time and place. The cells would then begin to move in the embryo due to their interfacial tensions and the nonequilibrium configuration in which they started. But what happens next?

The clue comes from our prediction (Gordon and Brodland, 1987) and discovery (Brodland et al., 1994; Gordon et al., 1994) of waves of contraction and expansion of the surfaces of epithelial cells in urodele amphibian embryos. Our best guess is that each wave in which a cell participates sends a one bit signal to its nucleus. If the wave is a contraction wave, the nucleus exposes one new subset of its genes (compared to the subset currently exposed), while if it is an expansion wave, it exposes an alternate subset of its genes (Björklund and Gordon, 1993b). Genes that are "exposed" are those available to be turned on or off, i.e., available for transcription. Sequestered genes are tucked away, so that they cannot be transcribed.

These "differentiation waves" have a mechanical component, which makes them simple to observe (Gordon and Björklund, 1996). Thus we hypothesize that the mechanics of the waves "controls" the genes. Of course, the genes then alter the boundary conditions, for instance, by synthesizing adhesion molecules, which then changes the shape, tissue configuration and mechanics of the embryo and probably thereby set up the conditions for launching the next waves. We thus see that the reality may be that there is a reciprocal relationship between the mechanics of an embryo and its genome, rather than either "controlling" the other. The "genetic program" is actually a "genome <--> physics" program. 


\section{Switching within networks or between networks?}

What is occurring inside the nucleus of a cell when the cell changes from one kind to another? Most models assume that the nucleus is an unorganized bag of chemicals (including the genes) arranged in a network of interactions. Such networks have "basins of attraction" that are presumed, somehow, to correspond to the states of differentiation of a cell (Delbrück, 1949; Kauffman, 1993; Huang and Ingber, 2000).

An alternative model starts from the observation that the nucleus has quite a bit of structure, with chromosomes in specific places (Miller et al., 1963a,b; Nagele et al., 1995, 1998) and orientations (Francis-Lang etal., 1996), with mechanical connections between them (Maniotis et al., 1997a), to the nuclear membrane and via the nuclear membrane all the way to the cell membrane (Maniotis et al., 1997b). We then take as a working model that the nucleus has a discrete physical structure, different for each cell type, and that its configuration changes when the cell changes from one type to another ( $\$ 10.13$ in Gordon, 1999). In each configuration, some genes are exposed, while others are sequestered. Thus, each configuration corresponds to a different network. The mechanical switching between nuclear configurations would, then, "control" which genes are expressed (Carroll et al., 1995).

\section{Consolidating differentiation waves with morphomechanics}

Roughly in parallel with our efforts on differentiation waves (Gordon and Brodland, 1987, 1989; Björklund and Gordon, 1993a,b; Brodland et al., 1994; Gordon et al., 1994) Lev V. Beloussov and his colleagues have worked out a mechanical approach to embryogenesis they call morphomechanics. The basic idea of "contact cell polarization" is that an epithelium with an internal pressure (perhaps 7 atm in amphibians; see p. 90 in Beloussov, 1998) can undergo a transition in which some cells contract their apical surfaces and the rest do not. Beloussov (Beloussov, 1998) attributes the theory explaining his observations to the late Boris Belintsev (Belintsev et al., 1985; Belintsev et al., 1987; Belintsev, 1991). There is no need for positional information: "...the model shows a way for a really delocalized regulation of morphogenetic processes, without each cell "knowing' its exact position...." (Beloussov, 1998; cf. (Beloussov et al., 1994).

Positioning of the boundary between contracted and (passively) expanded cells in the ectoderm is provided by its nonuniform strain state, which can be altered by relieving the strain over the whole surface (Beloussov et al., 1990), at the lateral margins (Yermakov and Beloussov, 1998), or at the dorsal lip of the blastopore (Beloussov and Snetkova, 1994; cf. Beloussov, 1988). I have similarly postulated that the strain state of the ectoderm determines the trajectory of the ectoderm contraction wave ( $\$ 9.25$ in Gordon, 1999). Slitting experiments in the neural plate reveal anisotropic tissue tensions (Jacobson and Gordon, 1976) that could affect differentiation waves that may be involved in segmentation of the neuroepithelium (Gordon et al., 1994). Convergenceextension movements in Xenopusalso involve anisotropic strains (Davidson and Keller, 1999). Thus we can see that my redefinition of the genetic program as a branching alternation of physics and gene expression (Proposition 14 in Gordon, 1999), can be extended to include the physics of morphomechanics:

1. one of a pair of differentiation waves produces:

2. change in gene expression in the cells propagating that wave, leading to:

3. change in strain state and other physical effects (electrical, etc.?), which result in:

4. launching of a pair of differentiation waves, etc. (i.e., go to \#1 for each wave).

All of these are subsumed in a single node of a differentiation tree ( $\$ 4.02$ in Gordon, 1999). To take into account the hypothesized mechanical events in the nucleus, the full, branching "cycle" becomes:

1. one of a pair of differentiation waves generate a:

2. one bit signal to the nucleus, which produces:

3. change in the structure of the nucleus, resulting in:

4. change in gene expression in the cells propagating that wave, creating:

5. change in strain state and other physical effects (electrical, etc.?), which result in:

6. launching of a pair of differentiation waves, etc. (go to \#1 for both waves).

This model reconciles the either genetics/or physics approaches (Beloussov et al., 1997) by incorporating both. Contact cell polarization, then, may be seen as setting up anisotropies that shape the trajectories of differentiation waves and perhaps create the mechanical conditions for their launching (Gordon and Brodland, 1987; though electrical phenomena may also be involved: $§ 9.27$ in Gordon, 1999). Morphomechanics may, further, explain the suggested mechanical dependence of the launching of one wave on the completion of another (a wave-wave interaction and relay mechanism), which could then explain the temperature independence of the sequence of developmental events in poikilothermic organisms (Proposition 82 in Gordon, 1999).

A number of observations suggest similarities and differences between contact cell polarization and differentiation waves:

1. The height programs in neurulation stage urodele embryos (Jacobson and Gordon, 1976; Gordon and Jacobson, 1978) may correspond to the maps of contact cell polarization in gastrulation stage anurans (Figure 2.26 in Beloussov, 1998). The rate of propagation of the latter phenomenon is 2 to $8 \mu \mathrm{m} / \mathrm{min}$ (Beloussov and Petrov, 1983; Petrov and Beloussov, 1984), comparable to the speed of the ectoderm contraction wave in axolotls of $3 \mu \mathrm{m} /$ min (Brodland et al., 1994) (expected to be slower because of the longer duration of gastrulation in axolotls compared to Xenopus).

2. Our empirical observation that a contraction wave in a given tissue may be followed slightly later by an active, epiboly-like expansion wave (Figure 16 in Gordon et al., 1994), launched at a distance in the same tissue, would seem to fit the Belintsev model (Belintsev etal., 1987). However, contracted ectoderm cells relax back to their previous apical diameters (Brodland et al., 1994), while contact cell polarization appears to persist in an "all-ornone" manner (Belintsev et al., 1987).

3. The theory of contact cell polarization assumes that contraction of a cell is active, while expansion is passive (Belintsev et al., 1987). Differentiation waves appear to be based on a tensegrity cytoskeletal apparatus, the "cell state splitter" (Brodland and Gordon, 1987; Chapter 3 in Gordon, 1999), which actively brings a cell to either an apically contracted or expanded state via 
contraction of the apical microfilament ring in a cell or expansion of an apical mat of microtubules oriented parallel to the apical surface (Gordon and Brodland, 1987). An intermediate filament ring provides elasticity and allows for a metastable state of the cell state splitter (Martin and Gordon, 1997), which presumably allows a cell to wait for a wave to impinge upon it.

4. The trajectory of the ectoderm contraction wave (Figure 17 in Gordon et al., 1994) covers the hemisphere of ectoderm that becomes the neural plate, while contact cell polarization appears to have a smaller trajectory (Figure 2.26 in Beloussov, 1998), though some contact cell polarizations do move in the cranial direction (Novoselov and Beloussov, 1990).

5. Beloussov suggests that it is a particular contact cell polarization wave, not all, that leads to cell differentiation (Beloussov, 1982), whereas every differentiation wave observed so far correlates with a step of differentiation (Gordon et al., 1994).

6. Beloussov (Beloussov, 1998) suggests that morphomechanics provides a solution to the problem of generally decreasing symmetry as an embryo develops. However, the same objection that I raised to Turing diffusion/reaction mechanisms (Turing, 1952) applies: there are multiple choices for symmetry breaking at each step ( $§ 1.09$ in Gordon, 1999). (Turing (Turing, 1952) in fact considered a mechanical alternative to his primarily chemical model for symmetry breaking: $\S 1.15$ in Gordon, 1999).

There are enough distinctions between contact cell polarization waves, which are of two distinct types (parallel and perpendicular to an epithelial surface (Beloussov, 1998)) and differentiation waves, to suggest that both (or all three) exist as separate phenomena. For example, the unexplored $50 \%$ apical area reduction of the neural plate as it changes from a hemisphere to a flat disk, certainly a massive columnarization (Figure 25 in Jacobson and Gordon, 1976), may be a contact cell polarization wave.

We thus see that the two contemporary approaches to mechanics in cell differentiation in embryos have much in common and need to be brought into one framework. They both show a central role for mechanics in embryogenesis. Thus mechanics in embryogenesis is hardly an irrelevant epiphenomenon.

\section{Stem cells and developmental mechanics}

The differentiation tree may be a useful guide to how to produce replacement tissues for our bodies. The egg could be our clone. Instead of using it to produce a whole infant and sacrificing it for parts (a bioethics nightmare), the undifferentiated egg could be proliferated (as in embryonic stem cells) and the cells then forced through a particular sequence of contractions and expansions. Such a "tissue synthesizer", following a specified differentiation code (Björklund and Gordon, 1994) might turn all the cloned cells into the one needed replacement tissue and rationalize the current cookbookery of how to get stem cells to differentiate the way we want them to. Of course, since each mechanical event of contraction or expansion of the apical surface of the cell is actually a mechanochemical event, we may find ways to intervene and accomplish execution of the differentiation code biochemically. The role of mechanics in stem cells is a burgeoning field, suggesting that its role may indeed be more than incidental (Wang et al., 2001; Banting et al., 2005; Kobayashi et al., 2004; Park et al., 2004; Roeder et al., 2005; Yamamoto et al., 2005;
Bakker et al., 2004; Kawanishi and Oikawa, 2004; Schild and Trueb, 2004; Marquez et al., 2004; Cui et al., 2004; Barkhausen etal., 2003; Naka et al., 2004; Berry etal., 2003; Yamamoto et al., 2003; Simmons et al., 2003; Yoshino et al., 2003; Wan et al., 2003; Sambajon et al., 2003; van Griensven et al., 2003; Altman et al., 2002; Pearson, 2003).

\section{Impact on embryonics}

Embryonics starts from the laudable goal that computers that grow by processes similar to embryos would be worth having for self-replication and self-repair (Sipper et al., 1997a,b; Mange et al., 1999, 2000; Restrepo et al., 2000; Sipper, 2002). However, the computers envisaged are rather stiff and unlifelike: "...the ultimate goal is to use huge chessboards - with billions of cells...", not at all like the liquid metal T-1000 robot in the movie Terminator 2: Judgment Day (1991). This is perhaps because embryonics has been based on one particular, perhaps erroneous model for embryo development: the concept of positional information, which requires a coordinate system for cells, an ability of each cell to determine its coordinates and a means of decoding what it is supposed to do by "looking up" those coordinates in its genome (Proposition 35 in (Gordon, 1999): "positional information does not exist"). Differentiation waves, by contrast, require only that a cell's genome respond to the sequence of contraction and expansion waves that the cell participates in. It need not know where it is at all. Waves in an active medium (Markin et al., 1987; Scott, 1970; Villar et al., 1996), which include differentiation waves, can be simulated on two and three dimensional tessellations (Gerhardt et al., 1990), but this is not essential: they can also propagate through a more flexible, less organized sheet, volume or spatial network of units with the same or better global effect (Markus, 1990, 1999).

It seems to me that an alternate physical model of computers is needed. Two kinds of computers are being developed that, if they were combined with the embryonics approach, might yield a better approximation to a growing, differentiating embryo. Modular robots are made of units that have motors and can configure and reconfigure themselves in many ways (Yim et al., 2002), going beyond simpler segmented robots (Hirose, 1993; Menzel and D'Aluisio, 2000). The other technology that is rapidly being developed is the wearable computer, building circuitry right into clothing (Mann, 2002; Mann and Hall Niedzviecki, 2002), one form of flexible electronics (Dorsch, 2001).

The modular robot units are $5 \mathrm{~cm}$ wide, but could be shrunk (Yim et al., 2002). A modular robot rearranges the units it has, but does not build new units from smaller components. Neither do cells. They, rather, double their essential components and then separate the components into two daughter cells. This takes a degree of internal flexibility that goes beyond present flexible electronics.

A new thrust into direct three dimensional growth of nanotechnology starting with single celled algae called diatoms (Gordon and Aguda, 1988; Gordon et al., 2005a)could help unite the field of cellular microrobotics (Fukuda and Ueyama, 1994) with embryonic robotics. An alternative approach would be to incorporate living cells into the electronics (Potter and DeMarse, 2001; Potter, 2001).

Robotics brings mechanics into computing. Embryonics brings 
the idea of imitating growth and differentiation into computing. I have shown that mechanics may be an essential component of real life embryos, so perhaps we should reach for embryonic robotics as the next goal, perhaps a little beyond what Wilhelm His imagined:

"But we must go further in our propositions. Embryology and morphology cannot proceed independently of all reference to the general laws of matter, - to the laws of physics and of mechanics. This proposition would, perhaps, seem indisputable to every natural philosopher; but, in morphological schools, there are very few who are disposed to adopt it with all its consequences"(His, 1888).

\section{Acknowledgements}

Supported in part by the Faculty of Medicine, University of Manitoba and the Manitoba Institute for Child Health.

\section{References}

ALBRECHT-BUEHLER, G. (1992). Rudimentary form of cellular «vision». Proc. Natl. Acad. Sci. USA 89: 8288-8292.

ALTMAN, G.H., LU, H.H., HORAN, R.L., CALABRO, T., RYDER, D., KAPLAN, D.L., STARK, P., MARTIN, I., RICHMOND, J.C. and VUNJAK-NOVAKOVIC, G. (2002). Advanced bioreactor with controlled application of multi-dimensional strain for tissue engineering. J Biomech Eng 124: 742-749.

ARNOLDI, M., FRITZ, M., BAUERLEIN, E., RADMACHER, M., SACKMANN, E. and BOULBITCH, A. (2000). Bacterial turgor pressure can be measured by atomic force microscopy. Phys Rev EStat Phys Plasmas Fluids Relat Interdiscip Topics 62 (1 Pt B): 1034-1044.

BAKKER, A., KLEIN-NULEND, J. and BURGER, E. (2004). Shear stress inhibits while disuse promotes osteocyte apoptosis. Biochem Biophys Res Commun 320: 1163-1168.

BANTING, G.S., BARAK, O., AMES, T.M., BURNHAM, A.C., KARDEL, M.D., COOCH, N.S., DAVIDSON, C.E., GODBOUT, R., MCDERMID, H.E. and SHIEKHATTAR, R. (2005). CECR2, a protein involved in neurulation, forms a novel chromatin remodeling complex with SNF2L. Hum Mol Genet 14: 513-524.

BARKHAUSEN, T., VAN GRIENSVEN, M., ZEICHEN, J. and BOSCH, U. (2003). Modulation of cell functions of human tendon fibroblasts by different repetitive cyclic mechanical stress patterns. Exp Toxicol Patho/55: 153-158.

BELINTSEV, B.N. (1991). Physical Foundations of Biological Morphogenesis [Russian]. Nauka, Moscow.

BELINTSEV, B.N., BELOUSSOV, L.V. and ZARAISKII, A.G. (1985). Model of epithelial morphogenesis based on elastic forces and cell contact polarization. Ontogenez 16: 5-14.

BELINTSEV, B.N., BELOUSSOV, L.V. and ZARAISKY, A.G. (1987). Model of pattern formation in epithelial morphogenesis. J Theor Bio/129: 369-394.

BELOUSSOV, L.V. (1982). Morphogenesis: relations and processes. Sov. Sci. Rev. D, Biol. Rev. 3: 343-370.

BELOUSSOV, L.V. (1988). Contact polarization of the cells of Xenopus laevis embryos during gastrulation. 2. Morphogenetic and differentiational consequences of relaxation polarization of the cells - relaxation morphoses. Ontogenez 19: 405-413

BELOUSSOV, L.V. (1998). The Dynamic Architecture of a Developing Organism: An Interdisciplinary Approach to the Development of Organisms. Kluwer Academic Publishers, Dordrecht.

BELOUSSOV, L.V., KAZAKOVA, N.I., LUCHINSKAIA, N.N. and NOVOSELOV, V.V. (1997). Studies in developmental cytomechanics. Int J Dev Bio/41: 793799.

BELOUSSOV, L.V., LAKIREV, A.V., NAUMIDI, I.I. and NOVOSELOV, V.V. (1990). Effects of relaxation of mechanical tensions upon the early morphogenesis of Xenopus laevis embryos. Int J Dev Bio/34: 409-419.

BELOUSSOV, L.V. and PETROV, K.V. (1983). The role of cellular interactions in differentiation of the induced embryonic tissues in amphibians. Onogenez 14: 21-29.
BELOUSSOV, L.V., SAVELIEV, S.V., NAUMIDI, I.I. and NOVOSELOV, V.V. (1994). Mechanical stresses in embryonic tissues: patterns, morphogenetic role and involvement in regulatory feedback. Int. Rev. Cytol. 150: 1-34.

BELOUSSOV, L.V. and SNETKOVA, E.V. (1994). The dependence of the differentiation potentials of fragments of the marginal zone in early gastrulas of the clawed toad on their morphogenetic movements. Ontogenez 25: 63-71.

BEN-ZE'EV, A. (1983). Cell configuration-related control of vimentin biosynthesis and phosphorylation in cultured mammalian cells. J Cel/ Bio/97: 858-865.

BEN-ZE'EV, A. (1984a). Control of intermediate filament protein synthesis by cellcell interaction and cell configuration. FEBS Lett 171: 107-110.

BEN-ZE'EV, A. (1984b). Differential control of cytokeratins and vimentin synthesis by cell-cell contact and cell spreading in cultured epithelial cells. J Cell Bio/99 (4 Pt 1): 1424-1433.

BEN-ZE'EV, A. (1985). Cell shape, the complex cellular networks and gene expression. Cytoskeletal protein genes as a model system. Cel/ Muscle Moti/6: 23-53.

BEN-ZE'EV, A. (1991). Animal cell shape changes and gene expression. BioEssays 13: 207-212.

BEN-ZE'EV, A., FARMER, S.R. and PENMAN, S. (1980). Protein synthesis requires cell-surface contact while nuclear events respond to cell shape in anchorage-dependent fibroblasts. Ce//21: 365-372.

BENNETT, C.L., HALPERN, M., HINSHAW, G., JAROSIK, N., KOGUT, A., LIMON, M., MEYER, S.S., PAGE, L., SPERGEL, D.N., TUCKER, G.S., WOLLACK, E., WRIGHT, E.L., BARNES, C., GREASON, M.R., HILL, R.S., KOMATSU, E., NOLTA, M.R., ODEGARD, N., PEIRIS, H.V., VERDE, L. and WEILAND, J.L. (2003). First year Wilkinson Microwave Anisotropy Probe (WMAP1) observations: preliminary maps and basic results. Astrophysical J. 148(suppl.): 1-27.

BERRY, C.C., SHELTON, J.C., BADER, D.L. and LEE, D.A. (2003). Influence of external uniaxial cyclic strain on oriented fibroblast-seeded collagen gels. Tissue Eng 9: 613-624.

BJÖRKLUND, N.K. and GORDON, R. (1993a). Nuclear state splitting: a working model for the mechanochemical coupling of differentiation «waves" with the controlling genes (master genes) [Russian]. Ontogenez 24: 5-23.

BJÖRKLUND, N.K. and GORDON, R. (1993b). Nuclear state splitting: a working model for the mechanochemical coupling of differentiation waves to master genes (with an Addendum). Russian J. Dev. Biol. 24: 79-95.

BJÖRKLUND, N.K. and GORDON, R. (1994). Surface contraction and expansion waves correlated with differentiation in axolotl embryos. I. Prolegomenon and differentiation during the plunge through the blastopore, as shown by the fate map. Computers \& Chemistry 18: 333-345.

BOOKSTEIN, F.L. (1978). The Measurement of Biological Shape and Shape Change. Springer-Verlag, Berlin.

BOOKSTEIN, F.L. (1991). Morphometric Tools for Landmark Data, Geometry and Biology. Cambridge University Press, New York.

BOOKSTEIN, F.L., CHERNOFF, B., ELDER, R.L., HUMPHRIES JR., J.M., SMITH, G.R. and STRAUSS, R.E. (1985). Morphometrics in Evolutionary Biology, The Geometry of Size and Shape Change, With Examples from Fishes. The Academy of Natural Sciences of Philidelphia, Philidelphia.

BORGENS, R.B., VANABLE JR., J.W. and JAFFE, L.F. (1977). Bioelectricity and regeneration: large currents leave the stumps of regenerating newt limbs. Proc. Natl. Acad. Sci. USA 74: 4528-4532.

BRODLAND, G.W. and GORDON, R. (1987). Mechanical instability of the cytoskeleton as a basis for primary neural induction. In BUTLER, D.L. and TORZILLI, P.A., 1987 Biomechanics Symposium, New York: American Society of Mechanical Engineers, p. 295-298.

BRODLAND, G.W., GORDON, R., SCOTT, M.J., BJÖRKLUND, N.K., LUCHKA, K.B., MARTIN, C.C., MATUGA, C., GLOBUS, M., VETHAMANY-GLOBUS, S. and SHU, D. (1994). Furrowing surface contraction wave coincident with primary neural induction in amphibian embryos. J. Morphol. 219: 131-142.

BURNSIDE, M.B. and JACOBSON, A.G. (1968). Analysis of morphogenetic movements in the neural plate of the newt Taricha torosa. Dev. Biol. 18: 537-552.

CARROLL, R.J., RUPPERT, D. and STEFANSKI, L.A. (1995). Measurement Error in Nonlinear Models, (1998 printing ed.), Chapman \& Hall/CRC, Boca Raton, Fla.

CHEN, C.S., MRKSICH, M., HUANG, S., WHITESIDES, G.M. and INGBER, D.E. (1997). Geometric control of cell life and death. Science 276: 1425-1428. 
CHEN, C.S., MRKSICH, M., HUANG, S., WHITESIDES, G.M. and INGBER, D.E. (1998). Micropatterned surfaces for control of cell shape, position and function. Biotechnol Prog 14: 356-363.

CILIBERTO, A., TYSON, J.J. and NOVAK, B. (1999). Mathematical model for early development of the sea urchin embryo. Gordon Research Conference on Oscillations and Dynamic Instabilities in Chemical Systems

CUI, W., BRYANT, M.R., SWEET, P.M. and MCDONNELL, P.J. (2004). Changes in gene expression in response to mechanical strain in human scleral fibroblasts. Exp Eye Res 78: 275-284.

DAVIDSON, L.A. and KELLER, R.E. (1999). Neural tube closure in Xenopus laevis involves medial migration, directed protrusive activity, cell intercalation and convergent extension. Development 126: 4547-4556.

DE JONG, H. (2002). Modeling and simulation of genetic regulatory systems: a literature review. J Comput Bio/9: 67-103.

DELBRÜCK, M. (1949). Discussion. In Unités biologiques douées de continuité génétique. Colloques Intern./Biological Units Endowed with Genetic Continuity. International Conferences, Lyon: Editions du CNRS, p. 33-35.

DIKE, L.E., CHEN, C.S., MRKSICH, M., TIEN, J., WHITESIDES, G.M. and INGBER, D.E. (1999). Geometric control of switching between growth, apoptosis and differentiation during angiogenesis using micropatterned substrates. In Vitro Cell Dev 35: 441-448.

DORSCH, J. (2001). Flexible electronics: on the brink of a tech revolution. SEMI Conductor Magazine 2: http://www.semi.org/web/wmagazine.nsf/ 4f55b97743c2d02e882565bf006c2459/8a7b262af0f00f8c88256afb0080dffe! OpenDocument

DRUM, R.W. and GORDON, R. (2003). Star Trek replicators and diatom nanotechnology. Trends Biotech. 21: 325-328.

EDELMAN, G.M. (1988). Topobiology, An Introduction to Molecular Embryology. Basic Books, New York.

EDELMAN, G.M. and JONES, F.S. (1998). Gene regulation of cell adhesion: a key step in neural morphogenesis. Brain Res Brain Res Rev 26: 337-352.

EMMECHE, C. (1994). The Garden in the Machine: The Emerging Science of Artificial Life. Princeton University Press, Princeton.

FARMER, S.R., WAN, K.M., BEN-ZE'EV, A. and PENMAN, S. (1983). Regulation of actin mRNA levels and translation responds to changes in cell configuration. Mol Cell Biol3: 182-189.

FRANCIS-LANG, H., DAVIS, I. and ISH-HOROWICZ, D. (1996). Asymmetric localization of Drosophila pair-rule transcripts from displaced nuclei: evidence for directional nuclear export. EMBO J15: 640-649.

FUKUDA, T. and UEYAMA, T. (1994). Cellular Robotics and Micro Robotic Systems. World Scientific Publishing Co., Singapore.

GERHARDT, M., SCHUSTER, H. and TYSON, J.J. (1990). A cellular automation model of excitable media including curvature and dispersion. Science 247: 1563-1566.

GLASER, O.C. (1914a). On the mechanism of morphological differentiation of the nervous system. I. The transformation of a neural plate into a neural tube. Anat. Rec. 8: 525-551.

GLASER, O.C. (1914b). The theory of autonomous folding in embryogenesis. Science 39: 730-731.

GLASER, O.C. (1916). The theory of autonomous folding in embryogenesis. Science 44: 505-509.

GORDON, R. (1999). The Hierarchical Genome and Differentiation Waves: Novel Unification of Development, Genetics and Evolution. World Scientific \& Imperial College Press, Singapore \& London.

GORDON, R. (2000). The emergence of emergence: a critique of «Design, observation, surprise!». Rivista di Biologia /Biology Forum 93: 349-356.

GORDON, R. (2006). Grasping for wholeness: a review of Stuart Pivar's Lifecode. Int. J. Dev. Biol. 50: 367-368.

GORDON, R. and AGUDA, B.D. (1988). Diatom morphogenesis: natural fractal fabrication of a complex microstructure. In HARRIS, G. and WALKER, C., Proc. of the Annual International Conference of the IEEE Engineering in Medicine and Biology Society, Part 1/4: Cardiology and Imaging, 4-7Nov. 1988, New Orleans, $\angle A, U S A$, New York: Institute of Electrical and Electronics Engineers, p. 273274.

GORDON, R., BJÖRKLUND, N.K. and NIEUWKOOP, P.D. (1994). Dialogue on embryonic induction and differentiation waves. Int. Rev. Cytol. 150: 373-420.

GORDON, R. and BJÖRKLUND, N.K. (1996). How to observe surface contraction waves on axolotl embryos. Int J Dev Bio/40: 913-914.

GORDON, R. and BRODLAND, G.W. (1987). The cytoskeletal mechanics of brain morphogenesis. Cell state splitters cause primary neural induction. Cel/ Biophys 11: 177-238.

GORDON, R. and BRODLAND, G.W. (1989). Neurulation. In ARMSTRONG, J.B. and MALACINSKI, G.M., Developmental Biology of the Axolotl, New York: Oxford University Press, p. 62-71.

GORDON, R., GOEL, N.S., STEINBERG, M.S. and WISEMAN, L.L. (1975). A rheological mechanism sufficient to explain the kinetics of cell sorting. In MOSTOW, G.D., Mathematical Models for Cell Rearrangement, New Haven: Yale University Press, p. 196-230.

GORDON, R. and JACOBSON, A.G. (1978). The shaping of tissues in embryos. Scientific American 238(6): 106-113.

GORDON, R. and PARKINSON, J. (2005). Potential roles for diatomists in nanotechnology. J. Nanosci. Nanotechnol. 5: 35-40.

GORDON, R., STERRENBURG, F.A.S. and SANDHAGE, K. (2005a). A Special Issue on Diatom Nanotechnology.J. Nanosci. Nanotechnol. 5: 1-4.

GORDON, R., BADEA, C.T., COLQUHOUN, G.D., UYTVEN, E.V., GUAN, H. and SARGENT, E.H. (2005b). Opinion. A contrary view of CTM (computed tomographic mammography): towards algorithms and new and futuristic scanners for 4D digital subtraction screening mammography. Technology in Cancer Research and Treatment: submitted.

HALFON, M.S. and MICHELSON, A.M. (2002). Exploring genetic regulatory networks in metazoan development: methods and models. Physio/ Genomics 10: 131-143.

HAROLD, F.M. (2001a). Postscript to Schrödinger: so what is life? ASM News 67: 611-616.

HAROLD, F.M. (2001b). The Way of the Cell: Molecules, Organisms and the Order of Life. Oxford University Press,

HAROLD, F.M. (2002). Force and compliance: rethinking morphogenesis in walled cells. Fungal Genet Bio/37: 271-282.

HAY, J.O., MOULIA, B., LANE, B., FREELING, M. and SILK, W.K. (2000). Biomechanical analysis of the Rolled ( $R L D$ ) leaf phenotype of maize. Am J Bot 87: 625-633.

HIROSE, S. (1993). Biologically Inspired Robots (Snake-like Locomotor and Manipulator). Oxford University Press, Oxford.

HIS, W. (1874). Unsere Körperform und das Problem ihrer Entstehung, Briefe an einen befreundeten Naturforscher/Our Body Form and the Problem of its Emergence, Letters to a Friendly Natural Scientist. F.C.W. Vogel, Leipzig.

HIS, W. (1888). On the principles of animal morphology. Roy. Soc. Edinburgh Proc. 15: $287-298$.

HO, M.W., STONE, T.A., JERMAN, I., BOLTON, J., BOLTON, H., GOODWIN, B.C., SAUNDERS, P.T. and ROBERTSON, F. (1992). Brief exposures to weak static magnetic field during early embryogenesis cause cuticular pattern abnormalities in Drosophila larvae. Phys. Med. Biol. 37: 1171-1179.

HO, M.-W. (1998). The Rainbow and the Worm: The Physics of Organisms, (2nd ed.), World Scientific, Singapore.

HOLLAND, J.H. (1998). Emergence: From Chaos to Order. Perseus Books, Reading, Massachusetts.

HUANG, S. and INGBER, D.E. (2000). Shape-dependent control of cell growth, differentiation and apoptosis: switching between attractors in cell regulatory networks. Exp Cell Res 261: 91-103.

HUANG, S. and INGBER, D.E. (2001). Regulation of cell cycle and gene activity patterns by cell shape: evidence for attractors in real regulatory networks and the selective mode of cellular control. In Proc. ICCS 1998.

INGBER, D.E. (1988). The architecture of life. Sci. Am. 278(1): 48-57.

INGBER, D.E. and FOLKMAN, J. (1989). Mechanochemical switching between growth and differentiation during fibroblast growth factor-stimulated angiogenesis in vitro: role of extracellular matrix. J. Cell Biol. 109: 317-330.

JACOBSON, A.G. and GORDON, R. (1976). Changes in the shape of the developing vertebrate nervous system analyzed experimentally, mathematically and by computer simulation. J. Exp. Zool. 197: 191-246. 
JAFFE, L.F., ROBINSON, K.R. and NUCCITELLI, R. (1974). Local cation entry and self-electrophoresis as an intracellular localization mechanism. Ann. NY Acad. Sci. 238: 372-389.

JAFFE, L.F. and STERN, C.D. (1979). Strong electrical currents leave the primitive streak of chick embryos. Science 206: 569-571.

JOHNSON, S. (2001). Emergence, The Connected Lives of Ants, Brains, Cities and Software. Scribner, New York.

KAUFFMAN, S.A. (1993). Origins of Order: Self-Organization and Selection in Evolution. Oxford University Press, New York.

KAVANAGH, A.J. and RICHARDS, O.W. (1942). Mathematical analysis of the relative growth of organisms. Proc. Rochester Acad. Sci. 8: 150-174.

KAWANISHI, S. and OIKAWA, S. (2004). Mechanism of telomere shortening by oxidative stress. Ann N Y Acad Sci1019: 278-284.

KELLER, E.F. (2000). Making Sense of Life: Explaining Biological Development with Models, Metaphors and Machines. Harvard University Press, Cambridge.

KELLER, R.E. (1984). The cellular basis of gastrulation in Xenopus laevis: active, postinvolution convergence and extension by mediolateral interdigitation. $\mathrm{Am}$ Zool. 24: 589-603.

KOBAYASHI, N., YASU, T., UEBA, H., SATA, M., HASHIMOTO, S., KUROKI, M., SAITO, M. and KAWAKAMI, M. (2004). Mechanical stress promotes the expression of smooth muscle-like properties in marrow stromal cells. Exp Hemato/32: 1238-1245.

LOEB, J. (1912). The Mechanistic Conception of Life, (1964 reprint ed.), Harvard University Press, Cambridge.

MANGE, D., SIPPER, M. and MARCHAL, P. (1999). Embryonic electronics. Biosystems 51: 145-152

MANGE, D., SIPPER, M., STAUFFER, A. and TEMPESTI, G. (2000). Toward robust integrated circuits: the embryonics approach. Proc. IEEE 88: 516-541.

MANIOTIS, A.J., BOJANOWSKI, K. and INGBER, D.E. (1997a). Mechanical continuity and reversible chromosome disassembly within intact genomes removed from living cells. J. Cell Biochem. 65: 114-130.

MANIOTIS, A.J., CHEN, C.S. and INGBER, D.E. (1997b). Demonstration of mechanical connections between integrins, cytoskeletal filaments and nucleoplasm that stabilize nuclear structure. Proc Nat/ Acad Sci USA 94: 849-854.

MANN, S. (2002). Intelligent Image Processing. Wiley-Interscience, New York.

MANN, S. and HALL NIEDZVIECKI (2002). Cyborg: Digital Destiny and Human Possibility in the Age of the Wearable Computer. Doubleday Canada Limited, Toronto.

MARKIN, V.S., PASTUSHENKO, V.F. and CHIZMADZHEV, Y.A. (1987). Theory of Excitable Media. John Wiley \& Sons, New York.

MARKUS, M. (1990). Modelling morphogenetic processes in excitable media using novel cellular automata. Biomed. Biochim. Acta 49: 681-696.

MARKUS, M. (1999). The BZ reaction as 'analog computer' for ubiquitous excitable media. Chem. Intelligencer 5: 48-50.

MARQUEZ, N., CHAPPELL, S.C., SANSOM, O.J., CLARKE, A.R., TEESDALESPITTLE, P., ERRINGTON, R.J. and SMITH, P.J. (2004). Microtubule stress modifies intra-nuclear location of Msh2 in mouse embryonic fibroblasts. Cell Cycle 3: 662-671.

MARTIN, C.C. and GORDON, R. (1995). Differentiation trees, a junk DNA molecular clock and the evolution of neoteny in salamanders. J. Evol. Biol. 8: 339-354.

MARTIN, C.C. and GORDON, R. (1997). Ultrastructural analysis of the cell state splitter in ectoderm cells differentiating to neural plate and epidermis during gastrulation in embryos of the axolotl Ambystoma mexicanum. Russian J. Dev. Biol. 28: 71-80.

MARTIN, C.C. and GORDON, R. (2001). The evolution of perception. Cybernetics \& Systems 32: 393-409.

MENZEL, P. and D'ALUISIO, F. (2000). Robo sapiens, Evolution of a New Species. MIT Press, Cambridge.

MILLER, O.J., BREG, W.R., MUKHERJEE, B.B. and GAMBLE, A. (1963b). Nonrandom distribution of chromosomes in metaphase figures from cultured human leukocytes. 1 The peripheral location of chromosomes 13, 17, 18 and 21 . Cytogenetics 2: 152-167.

MILLER, O.J., MUKHERJEE, B.B., BREG, W.R. and GAMBLE, A. (1963a). Nonrandom distribution of chromosomes in metaphase figures from cultured human leukocytes. The peripheral location of the $Y$ chromosome. Cytogenetics 2: 1-14

MOONEY, D., HANSEN, L., VACANTI, J., LANGER, R., FARMER, S. and INGBER D. (1992). Switching from differentiation to growth in hepatocytes: control by extracellular matrix. J. Cell Physiol. 151: 497-505

MOROWITZ, H.J. (2002). The Emergence of Everything, How the World Became Complex. Oxford University Press, Oxford.

NAGELE, R., FREEMAN, T., MCMORROW, L. and LEE, H.Y. (1995). Precise spatial positioning of chromosomes during prometaphase: evidence for chromosomal order. Science 270: 1831-1835.

NAGELE, R.G., FREEMAN, T., FAZEKAS, J., LEE, K.M., THOMSON, Z. and LEE, H.Y. (1998). Chromosome spatial order in human cells: evidence for early origin and faithful propagation. Chromosoma 107: 330-338.

NAKA, K., TACHIBANA, A., IKEDA, K. and MOTOYAMA, N. (2004). Stress-induced premature senescence in hTERT-expressing ataxia telangiectasia fibroblasts. $\checkmark$ Biol Chem 279: 2030-2037.

NOVOSELOV, V.V. and BELOUSSOV, L.V. (1990). Variation of dorsal ectoderm polarization in Xenopus laevis embryos during normal development and in response to strain relaxation. Ontogenez 21: 480-486.

OPPENHEIMER, J.M. (1967). Essays in the History of Embryology and Biology. M.I.T. Press, Cambridge.

PARK, J.S., CHU, J.S., CHENG, C., CHEN, F., CHEN, D. and LI, S. (2004) Differential effects of equiaxial and uniaxial strain on mesenchymal stem cells. Biotechnol Bioeng 88: 359-368.

PAULY, P.J. (1987). Controlling Life, Jacques Loeb and the Engineering Ideal in Biology. University of California Press, Berkeley.

PEARSON, H. (2003). Stretching changes stem cells' fate. Cells under tension make bone not fat. Nature Science Update (13 December): http:// www.seas.upenn.edu/ chenlab/newsreleases/NatureSU\%20Stem.pdf

PETROV, K.V. and BELOUSSOV, L.V. (1984). The kinetics of contact polarization of the cells in the induced tissues of amphibian embryos. Ontogenez 15: 643648.

PHILLIPS, H.M. and STEINBERG, M.S. (1969). Equilibrium measurements of embryonic chick cell adhesiveness, I. Shape equilibrium in centrifugal fields Proc. Natl. Acad. Sci. USA 64: 121-127.

PHILLIPS, H.M. and STEINBERG, M.S. (1978). Embryonic tissues as elasticoviscous liquids I. Rapid and slow shape changes in centrifuged cell aggregates. J. Cell Sci. 30: 1-20.

PHILLIPS, H.M., STEINBERG, M.S. and LIPTON, B.H. (1972). Elasticoviscous morphogenetic behaviour of centrifuged chick cell aggregates. Amer. Zool. 12: 699.

PHILLIPS, H.M., STEINBERG, M.S. and LIPTON, B.H. (1977). Embryonic tissues as elasticoviscous liquids II. Direct evidence for cell slippage in centrifuged aggregates. Dev. Biol. 59: 124-134.

PIVAR, S. (2004). Lifecode, The Theory of Biological Self Organization. Ryland Press, New York.

POTTER, S.M. (2001). Distributed processing in cultured neuronal networks. Prog Brain Res 130: 49-62.

POTTER, S.M. and DEMARSE, T.B. (2001). A new approach to neural cell culture for long-term studies. J Neurosci Methods 110: 17-24.

PROBST, W.C., SNYDER, L.A., SCHUSTER, D.I., BROSIUS, J. and SEALFON, S.C. (1992). Sequence alignment of the G-protein coupled receptor superfamily. DNA Cell Bio/11: 1-20.

RESTREPO, H.F., MANGE, D. and SIPPER, M. (2000). A Self-Replicating Universal Turing Machine: From von Neumann's Dream to New Embryonic Circuits. In BEDAU, M.A., MCCASKILL, J.S., PACKARD, N.H. and RASMUSSEN, S. Artificial Life VII: Proc. of the Seventh International Conference on Artificial Life, Cambridge: MIT Press.

RICHARDS, O.W. and KAVANAGH, A.J. (1943). The analysis of the relative growth gradients and changing form of growing organisms: illustrated by the tobacco leaf. American Naturalist 77: 385-399.

RICHARDS, O.W. and KAVANAGH, A.J. (1945). Tha analysis of growing form. In LE GROS CLARK, E.E. and MEDAWAR, P.B., Essays on Growth and Form presented to D'Arcy Wentworth Thompson, Oxford: Clarendon Press, p. 188230.

ROBINSON, K.R. and JAFFE, L.F. (1975). Polarizing fucoid eggs drive a calcium 
current through themselves. Science 187: 70-72.

ROEDER, I., KAMMINGA, L.M., BRAESEL, K., DONTJE, B., DE HAAN, G. and LOEFFLER, M. (2005). Competitive clonal hematopoiesis in mouse chimeras explained by a stochastic model of stem cell organization. Blood105: 609-616.

RONALD, E.M.A., SIPPER, M. and CAPCARRÈRE, M.S. (1999). Design, Observation, Surprise! A Test of Emergence. Artif Life 5: 225-239.

ROUX, W. (1888). Contributions to the developmental mechanics of the embryo. On the artificial production of half-embryos by destruction of one of the first two blastomeres and the later development (postgeneration) of the missing half of the body. In WILLIER, B.H. and OPPENHEIMER, J.M., Foundations of Experimental Embryology, Englewood Cliffs, New Jersey: Prentice-Hall, p. 2-37.

SAMBAJON, V.V., CILLO, J.E. JR, GASSNER, R.J. and BUCKLEY, M.J. (2003). The effects of mechanical strain on synovial fibroblasts. J Oral Maxillofac Surg 61: 707-712.

SAUSEDO, R.A., SMITH, J.L. and SCHOENWOLF, G.C. (1997). Role of nonrandomly oriented cell division in shaping and bending of the neural plate. J Comp Neuro/381: 473-488.

SCHILD, C. and TRUEB, B. (2004). Three members of the connective tissue growth factor family $\mathrm{CCN}$ are differentially regulated by mechanical stress. Biochim Biophys Acta 1691: 33-40.

SCHLIWA, M. (ed.) (2002). Molecular Motors, Wiley-VCH, Weinheim.

SCOTT, A.C. (1970). Active and Nonlinear Wave Propagation in Electronics. John Wiley \& Sons, New York.

SIMMONS, C.A., MATLIS, S., THORNTON, A.J., CHEN, S., WANG, C.Y. and MOONEY, D.J. (2003). Cyclic strain enhances matrix mineralization by adult human mesenchymal stem cells via the extracellular signal-regulated kinase (ERK1/2) signaling pathway. J Biomech 36: 1087-1096.

SINNOTT, E.W. (1960). Plant Morphogenesis. McGraw-Hill Book Co., New York. SIPPER, M., MANGE, D. and STAUFFER, A. (1997a). Ontogenetic hardware. Biosystems 44: 193-207.

SIPPER, M., SANCHEZ, E., MANGE, D., TOMASSINI, M., P $f$ REZ-URIBE, A. and STAUFFER, A. (1997b). A phylogenetic, ontogenetic and epigenetic view of bio-inspired hardware systems. IEEE Trans. Evol. Computation 1: 83-97.

SIPPER, M. (2002). Machine Nature: The Coming Age of Bio-Inspired Computing. McGraw-Hill Trade,

SMITH, L.G., HAKE, S. and SYLVESTER, A.W. (1996). The tangled-1 mutation alters cell division orientations throughout maize leaf development without altering leaf shape. Development 122: 481-489.

STEINBERG, M.S. (1963). Reconstruction of tissues by dissociated cells. Science 141: 401-408.

STEINBERG, M.S. (1996). Adhesion in development: an historical overview. Dev.
Biol. 180: 377-388.

THOMPSON, D.W. (1917). On Growth and Form. University Press, Cambridge.

THOMPSON, D.W. (1942). On Growth and Form, (2nd ed.), Cambridge University Press, Cambridge.

TOWNES, P.L. and HOLTFRETER, J. (1955). Directed movements and selective adhesion of embryonic amphibian cells. J. Exp. Zool. 128: 53-120.

TURING, A.M. (1952). The chemical basis of morphogenesis. Phil. Trans. Roy. Soc. London B237: 37-72.

TYSON, J.J., CHEN, K. and NOVAK, B. (2001). Network dynamics and cell physiology. Nat Rev Mol Cell Biol2: 908-916.

VAN GRIENSVEN, M., ZEICHEN, J., SKUTEK, M., BARKHAUSEN, T., KRETTEK, C. and BOSCH, U. (2003). Cyclic mechanical strain induces NO production in human patellar tendon fibroblasts-a possible role for remodelling and pathological transformation. Exp Toxicol Patho/54: 335-338.

VILLAR, V.P., MUNUZURI, V.P., PÉREZ GARCIA, C.P. and KRINSKY, V.I. (eds.) (1996). New Trends in Pattern Formation in Active Nonlinear Media, World Scientific, Singapore.

WAN, Y., YANG, J., YANG, J., BEI, J. and WANG, S. (2003). Cell adhesion on gaseous plasma modified poly-(L-lactide) surface under shear stress field. Biomaterials 24: 3757-3764.

WANG, J.H., GOLDSCHMIDT-CLERMONT, P., WILLE, J. and YIN, F.C. (2001). Specificity of endothelial cell reorientation in response to cyclic mechanical stretching. J Biomech 34: 1563-1572.

YAMAMOTO, K., SOKABE, T., WATABE, T., MIYAZONO, K., YAMASHITA, J.K., OBI, S., OHURA, N., MATSUSHITA, A., KAMIYA, A. and ANDO, J. (2005). Fluid shear stress induces differentiation of Flk-1-positive embryonic stem cells into vascular endothelial cells in vitro. Am J Physiol Heart Circ Physio/ H1915-1924.

YAMAMOTO, K., TAKAHASHI, T., ASAHARA, T., OHURA, N., SOKABE, T., KAMIYA, A. and ANDO, J. (2003). Proliferation, differentiation and tube formation by endothelial progenitor cells in response to shear stress. J App/ Physiol 95: 2081-2088.

YERMAKOV, A.S. and BELOUSSOV, L.V. (1998). Variability and asymmetry of the axial rudiments in Xenopus laevis embryos after the disturbance of cell movements and tensile fields in the marginal zone of early gastrulae. Ontogenez29: 38-46.

YIM, M., ZHANG, Y. and DUFF, D. (2002). Modular robots. IEEE Spectrum 39: 3034.

YOSHINO, H., MORITA, I., MUROTA, S.I. and ISHIKAWA, I. (2003). Mechanical stress induces production of angiogenic regulators in cultured human gingival and periodontal ligament fibroblasts. J Periodontal Res 38: 405-410. 